\title{
Nematicidal Potential of some Natural Botanical Extracts in Biocontrolling Meloidogyne javanica on Soybean under Laboratory and Greenhouse Conditions
}

\author{
Sahar H. Abdel-Baset and Montaser F. Abdel-Monaim \\ Plants Pathol. Res. Inst., ARC, Giza, Egypt \\ Corresponding author email: drsaharhassan14@gmail.com
}

\begin{abstract}
The nematicidal potential of certain plant part extracts against Meloidogyne javanica was determined under in vitro and in vivo experiments. Three different solvents were used in the preparation of the tested extracts including water, ethyl alcohol and acetone. The extracted plants included Eugenia jambolana (leaves), Punica granatum (Peels) and Camellia sinensis (Leaves). Results showed that ethyl alcohol peel extract of E. jambolana, and $P$. granatum completely inhibited the egg hatching of $M$. javanica while, ethyl alcohol leaf extract of $C$. sinensis inhibited the egg hatching by $60 \%$. Nematode juveniles $\mathrm{j}_{2}$ mortality gradually increased as the exposure time increased from 24 to 48 hours. Under greenhouse conditions, organic solvent extracts of all the tested plants were more effective in suppressing the nematode reproduction compared to the aqueous extracts. The ethyl alcohol leaf extract of E. jambolana completely suppressed the gall formation by $M$. javanica on soybean roots as well as number of egg-masses/plant, and the number of $\mathrm{J}_{2} \mathrm{~s}$ in soil. Ethyl alcohol peel extract of $P$. granatum showed the greatest nematicidal effects against $M$. javanica, while its aqueous extract was the least effective. The plants treated with the ethyl alcohol leaf extract of E. jambolana, showed the highest increase in the plant growth parameters $v i z$., shoot weight, and length as well as root weight and length compared to the control treatment. Chemical analysis of leaf extract of E. jambolana by gas chromatography-mass spectrometry (GC-MS) showed that it contained thirty-three bioactive compounds, including, flavonoids, antioxidant, oxygenated hydrocarbons, unsaturated fatty acids, sterile, fatty acid ester, triterpene, and others. All plant extracts increased the activities of defense-related enzymes, including peroxidase, catalase, chitinase, $\beta-1,3$-glucanase enzymes as well as, the total phenol contents in soybean plants infected with $M$. javanica under greenhouse conditions.
\end{abstract}

Key words: Glycine max, Meloidogyne javanica, nematicidal effects, resistance enzymes, phenolic compounds, botanical extracts.

\section{INTRODUCTION}

Soybean, Glycine $\max$ (L.) Merr, is considered to be one of the most important legumes and oilseed crops cultivated in the world. Soybean is used for food, feed, and the processing of raw materials for the vegetable oil industry and other purposes as well. The cultivated areas account 121.53 million ha, worldwide with a total production of about 334.89 million metric tons in 2018 (FAO. 2018). Egypt has shown great interest in soybean cultivation due to the increasing lack of dietary 
protein, as soybean protein provides all nine essential amino acids that considered the main protein source for human and animal consumption (Liebenberg, 2012).

Plant parasitic nematodes are major biotic factors that negatively affect the soybean production worldwide, causing an annual yield loss of about 10-15\%. More than 100 nematode species belonging to 50 genera have been reported in association with soybeans. Of them, root-knot nematodes, Meloidogyne spp., and soybean cyst nematode, Heterodera glycines, are notably the most important nematodes attacking soybean plants worldwide. They, especially, cause deformation of the soybean root systems when galls are formed and consequently the nutrient and water uptake by these roots is adversely affected (Sikora et al., 2005 a, b). The most damaging species were found to be $M$. javanica and $M$. incognita which cause significant yield loss of susceptible soybean cultivars by as much as $90 \%$ (Fourie et al., 2001).

The continuous use of the classical nematicides to control plant-parasitic nematodes are likely to cause phytotoxicity, pollution of the environment and resistance to the nematode (Conway, 1995 \&Yudelman et al., 1998). One of the effective control alternatives is the use of botanical extracts, which are safe, cheap and easy to use (Sultana et al., 2010, Khan et al., 2011). El- Nagdi and Youssef (2014) reported that aqueous extract of P.granatum as mashed fruit peels recorded $61.1 \%$ reduction in the number of the hatched juveniles of M.incognia and $87.7 \%$ in the number of juveniles in sugar beet soil. Some plants used for the nematode management to produce secondary compounds which do not only activate defense mechanisms of the treated plants, but also might have anti-pathogenic activity against plant nematodes (Stangarlin et al., 2011).

A large number of enzymes are associated with induced resistance in plants against plant pathogens (Ojaghian et al., 2014). These enzymes include; peroxidases, $\beta$-1,3-glucanases, and chitinases. $\beta$-1,3-glucans and chitinase can degrade the cell walls of the pathogens, releasing molecules that act as elicitors in the initial stages of the resistance induction process of phytoalexins and phenolic compounds (Silva et al., 2004). In general, peroxidase plays a fundamental role in the growth and development of plants and is strongly related to defense mechanisms against pathogens (Kurabachew and Wydra, 2014). Generally, chitinase may play a secondary function as signal molecules, which elicit the induction of other pathogenesis-related (PR) proteins or metabolites, involved in plant-defense reactions (Rahimi et al., 1998). The objectives of this study: 1- evaluation of the effect of certain plant extracts on controlling the root-knot nematode, $M$. javanica on soybean plants under greenhouse conditions.2- determination of the bio-active, and chemical constituents of leaves extract by using GC/MS of Eugenia jambolana.3determination of the biochemical changes in soybean plants treated with natural plant extracts.

\section{MATERIALS AND METHODS}

\section{Preparation of plant extracts}

\section{A: Aqueous plant extracts:}

Plants of three species belonging to three genera Table (1) were collected from different localities in El-Kharga, New Valley Governorate, Egypt. Leaves and/or peels of the collected plants were cut into small pieces, washed several times with running tap water, then with sterile water and air-dried at room temperature $\left(\approx 25^{\circ} \mathrm{C}\right)$ 
for 15 days. Plant materials were ground to fine powders in a grinder, then a100 $\mathrm{g}$ of each one was blended in $1 \mathrm{~L}$ of distilled water for 6 hours. The ground materials were squeezed through double cheesecloth sheets, then filtered through a Whattman No. 1 filter paper. The efficacy of the fresh extracts was evaluated against $M$. javanica $\mathrm{J}_{2} \mathrm{~S}$ at the concentration of $20 \%$ from the original ones (Abdel-Monaim et al., 2011).

Table 1: A list of the plant species and their parts that were tested for their nematicidal activity against Meloidogyne javanica.

\begin{tabular}{|l|l|l|l|}
\hline $\begin{array}{l}\text { Common } \\
\text { name }\end{array}$ & Family name & \multicolumn{1}{|c|}{ Scientific name } & Used parts \\
\hline Stopper & Myrtaceae & $\begin{array}{l}\text { Eugenia jambolana (Syn.Syzygiumcumini or } \\
\text { Syzygium jambolana } \text { or Eugenia cuminii) }\end{array}$ & Leaves \\
\hline Pomegranate & Lythraceae & Punica granatum & Fruit peels \\
\hline Green tea & Theaceae & Camellia sinensis & Leaves \\
\hline
\end{tabular}

\section{B: Organic solvents of plant extracts:}

In this experiment, two organic solvents, i.e. ethanol $95 \%$ and acetone were used for preparing the plant extracts. The method was the same applied to the aqueous plant extracts except using organic solvents instead of distilled water. The extracted materials with each of the solvents were concentrated by a rotary vacuum evaporator at $50^{\circ} \mathrm{C}$ for 6 hours. The final concentration was prepared as those of water extracts (20\%) by adding water for each organic solvent extract (Abdel-Monaim et al., 2011).

Nematode inocula: A pure culture of $M$. javanica was obtained from tomato plants grown in clay pots in the greenhouse. Nematode eggs were extracted from the $M$. javanica-infected tomato roots by the $\mathrm{NaOCl} 0.5 \%$ (Hussey and Barker, 1973). Eggs were then used immediately for hatching tests or incubated in water for juvenile hatching at room temperature. The freshly hatched $\mathrm{J}_{2} \mathrm{~S}$ were used for the evaluations of aqueous or solvent extracts.

\section{2- Laboratory assay}

\section{A- Hatchability test:}

One-ml of $M$. javanica egg suspension (about 100 eggs $/ \mathrm{ml}$ ) and nine-ml of each plant extract (whether aqueous or solvent plant extract) were transferred to glass cavity blocks and kept at room temperature $\left(\approx 25^{\circ} \mathrm{C}\right)$. An equal number of glass cavities containing $1-\mathrm{ml}$ of the egg suspension and nine - $\mathrm{ml}$ distilled water served as controls. Each treatment was replicated thrice. After four days of exposure, the number of hatching juveniles was counted under a stereoscopic microscope. The toxicity of plant extracts was assessed as the mean percentages egg hatching inhibition.

\section{B- Effect of plant extracts on juvenile mortality:}

Nine $\mathrm{ml}$ of each plant extract was separately poured into each Petri dish was added to1 one- $\mathrm{ml}$ of the nematode suspension containing 100 freshly hatched juveniles. The Petri dishes with distilled water taken as control. All treatments were replicated three times. The Petri dishes were incubated at room temperature $\left(\approx 25^{\circ} \mathrm{C}\right)$. 
Percentages juvenile mortality were calculated after 24 and 48 hours using Abbott's formula (Abbott, 1925) as follows:

Mortality $(\%)=[$ (mortality percentage in treatment - mortality percentage in control $) /(100-$ mortality percentage in control $)] \times 100$.

The greenhouse experiments were conducted during the summer season, 2018 at the New Valley Agriculture Research Station.

\section{3- Greenhouse experiment}

Fifty clay pots, $30 \mathrm{-cm}$ diameter (five $\mathrm{kg}$ capacity) were, filled with a steamsterilized mixture of sandy clay (4:1) soil. Three seeds of soybean cv. "Giza 35" were planted in each pot, and the seedlings were thinned to one seedling/pot, 7 days after emergence. Each seedling was inoculated with 2000 eggs of M. javanica. Nine plant extracts plus a control (10 treatments), with five replicates each, were established as follows:

1- E. jambolana aqueous leaf extract $+M$. javanica .

2- E. jambolana ethyl alcohol leaf extract $+M$. javanica.

3-E. jambolana acetone leaf extract $+M$. javanica.

4. $P$. granatum aqueous leaf extract $+M$. javanica.

5- $P$. granatum ethyl alcohol peel extract $+M$. javanica.

6- $P$. granatum acetone peel extract $+M$. javanica.

7- $C$. sinensis aqueous leaf extract $+M$. javanica.

8- C. sinensis ethyl alcohol leaf extract $+M$. javanica.

9- $C$. sinensis acetone leaf extract $+M$. javanica.

10- Cotrol (M. javanica only).

The plant extracts were added three times as follows: A- two days before nematode inoculation, B- Simultanously with nematode inoculation and, C- two days after nematode inoculation.

The extracts were added @ $40 \mathrm{ml} /$ pot by pouring the solution into holes made around the seedlings in each pot. Plants inoculated with $M$. javanica only served as control. Pots were arranged in a completely randomized design with five replicates for each treatment.

Sixty days after inoculation, the experiment was terminated. Root systems were gently washed with tap water and stained with Phloxine B (0.15 g/l liter water) for 20min. to emphasize the presence of egg masses (Daykin and Hussey, 1985). Numbers of root galls, and egg masses/root system were counted and indexed on a $0-5$ scale (Taylor and Sasser 1978), where 0: = no galls (or egg masses), $1=1-2,2=3-10,3$ $=11-30,4=31-100,5=$ more than 100 galls (or egg masses) /root system. Secondstage juveniles $\left(\mathrm{J}_{2} \mathrm{~S}\right)$ were extracted from an aliquot of $250 \mathrm{~g}$ soil from each pot using sieving and Baermann pan technique (Barker et al., 1985). The extracted juveniles were counted using 1-ml counting slide under a compound microscope. Finally, shoot and root lengths $(\mathrm{cm})$, and shoot and root fresh and dry weights $(\mathrm{g})$ were measured.

\section{4-Gas chromatography-mass spectrometry (GC/MS) analysis}

The protocol for GC-MS analysis was performed according to (Weckwerth et al., 2004). The analysis extract of E. jambolana was carried-out using a GC (Agilent Technologies 7890A) interfaced with a mass-selective detector (MSD, Agilent 7000) equipped with a polar Agilent HP-5ms (5\%-phenyl methyl poly siloxane) capillary 
column $(30 \mathrm{~m} \times 0.25 \mathrm{~mm}$ i. d. and $0.25 \mu \mathrm{m}$ film thickness $)$. The carrier gas was helium with the linear velocity of $1 \mathrm{ml} / \mathrm{min}$. The injector and detector temperatures were 200 and $250{ }^{\circ} \mathrm{C}$, respectively. The volume of injection of each sample was $1 \mu$. The MS operating parameters were as follows: ionization potential $70 \mathrm{eV}$, interface temperature $250{ }^{\circ} \mathrm{C}$, and acquired mass range 50-800, the identification of components was based on a comparison of their mass spectra and retention time with those of the authentic compounds and by computer matching with NIST and WILEY library as well as by comparison of the fragmentation pattern of the mass spectral data with those reported in the literature. This was carried out by the Regional Center for Food \& Feed, Agricultural Research Center, Giza.

5-Biochemical changes in soybean plants treated with some natural plant extracts in soil infested with M. javanica under greenhouse conditions

Clay pots, $30-\mathrm{cm}$ diam. (4-kg soil capacity) were filled with a sterilized mixture of clay and sand (4:1), and planted with soybean seeds cv. "Giza 35". Seven days after emergence, seedlings were thinned to one seedling/pot and inoculated with 500 eggs of $M$. javanica/seedling. Plant extracts were added as mentioned previously. Each treatment was replicated 3 times, and pots were arranged in a complete randomized design. Three days after the third extract addition, one $g$ of root tissues from each treatment was used for enzyme extraction according to McCord and Fridovich (1969).

Peroxidase activity: The activity of peroxidase enzyme was determined directly using a spectrophotometrical method according to Hammerschmidt et al. (1982). Activity was expressed as units $\min ^{-1}$ (mg protein $)^{-1}$.

Catalase activity: The activity of catalase was assayed according to Verma and Dubey (2003). Activity was expressed as units $\min ^{-1}$ (mg protein) ${ }^{-1}$.

Chitinase activity: The Chitinase activity was determined using the method described by (Wirth and Wolf, 1992). Enzyme activity was expressed as an enzyme $\min ^{-1}$ (mg protein $)^{-1}$.

$\beta$-1,3-glucanase:m $\beta$-1,3-glucanase activity was assayed by the laminarindinitrosalicylic acid method (Pan et al., 1991). The enzyme activity was expressed as $\mu \mathrm{g}$ glucose released $\min ^{-1}(\mathrm{mg} \text { protein })^{-1}$. Increasing percentages $(\%)$ of enzyme activity were counted in comparison with a control treatment.

\section{Determination of phenolic compounds}

For assessing the total phenolic contents, $1 \mathrm{~g}$ fresh root of each treatment was homogenized in $10 \mathrm{ml}$ of $80 \%$ methanol and agitated for $15-\mathrm{min}$. at $70{ }^{\circ} \mathrm{C}$. One $\mathrm{ml}$ of the extract was added to $5-\mathrm{ml}$ distilled water plus $250 \mu \mathrm{l}$ of $1 \mathrm{~N}$ Folin-Ciocalteau reagent, and the solution was kept at $25^{\circ} \mathrm{C}$. The absorbance was measured with a spectrophotometer at $725-\mathrm{nm}$. Catechol was used as a standard. The amount of phenolic content was expressed as phenol equivalents in $\mathrm{mg} / \mathrm{g}$ fresh tissue (Saikia et al., 2006). Increasing percentages (\%) of total phenolic contents were counted in comparison with a control treatment. 
Statistical analysis

All experiments were performed twice. Analyses of variance were carried-out using MSTAT-C program version 2.10 (Anonymous,1991). Means were separated using the least significant differences (LSD) method at $P \leq 0.05$ (Gomez and Gomez, 1984).

\section{RESULTS}

\section{Egg hatching and juvenile mortality:}

All extracts affected egg hatching and juvenile mortality of $M$. javanica Table (2). Ethyl alcohol extracts of E. jambolana (Leaves), and $P$. granatum (Peels) completely inhibited egg hatching of $M$. javanica after 4 days. However, the ethyl alcohol leaf extract of $C$. sinensis inhibited the egg hatching by $60 \%$. Nematode juvenile mortality gradually increased as the exposure time increased Table (2).

It was noticed that ethyl alcohol extracts of E. jambolana (Leaves), and $P$. granatum (Peels) caused $100 \%$ mortality after 48 hours. But, ethyl alcohol leaf extract of C.sinensis caused $65 \%$ mortality after the same time. The least effective treatment was a acetone leaf extract of $C$. sinensis, as it recorded $32 \%$ only after 48 hours.

Table 2: Effects of some plant extracts on egg hatching of Meloidogyne javanica in vitro.

\begin{tabular}{|c|c|c|c|c|}
\hline \multirow[t]{2}{*}{ Plant extracts } & \multirow{2}{*}{$\begin{array}{c}\text { Extraction } \\
\text { medium } \\
\text { (Solvents) }\end{array}$} & \multirow{2}{*}{$\begin{array}{c}\text { \% of egg } \\
\text { hatching } \\
\text { inhibition } \\
\text { after4days }\end{array}$} & \multicolumn{2}{|c|}{ Juvenile mortality (\%) } \\
\hline & & & After 24 hours & After 48 hours \\
\hline \multirow[t]{3}{*}{ Eugenia jambolana } & Distilled water & 23 & 26 & 42 \\
\hline & Ethyl alcohol & 100 & 62 & 100 \\
\hline & Acetone & 44 & 38 & 64 \\
\hline \multirow[t]{3}{*}{ Punica granatum } & Distilled water & 38 & 21 & 53 \\
\hline & Ethyl alcohol & 100 & 54 & 100 \\
\hline & Acetone & 50 & 30 & 48 \\
\hline \multirow[t]{3}{*}{ Camellia sinensis } & Distilled water & 56 & 23 & 50 \\
\hline & Ethyl alcohol & 60 & 38 & 65 \\
\hline & Acetone & 42 & 17 & 32 \\
\hline $\begin{array}{l}\text { Control ( distilled } \\
\text { water) }\end{array}$ & & 0.0 & 0.0 & 0.0 \\
\hline \multicolumn{5}{|c|}{$\mathrm{LSD}_{0.05}$} \\
\hline Plant extracts $(\mathrm{A})=$ & - & 4.41 & 6.1 & 5.9 \\
\hline Solvents $(\mathrm{B})=$ & - & 4.41 & 6.1 & 5.9 \\
\hline Interactions $(\mathrm{A} \times \mathrm{B})=$ & - & 7.63 & 10.48 & 10.21 \\
\hline
\end{tabular}

Data are averages of 3 replicates.

\section{Greenhouse experiment}

\section{Effect of some natural plant extracts on soybean infected with $M$. javanica under greenhouse conditions}

Results of the nematicidal effect of some aqueous and organic solvent extracts of $E$. jambolana, $P$. granatum and $C$. sinensis against $M$. javanica reproduction on soybean plant are shown in Table (3). All treatments significantly reduced the root 
galling and $M$. javanica reproduction on soybean plants. Generally, organic solvent extracts of all the tested plants were more effective in reducing nematode reproduction than aqueous extracts.

Table 3: Effect of some natural plant extracts on root galling and nematode reproduction of Meloidogyne javanica infecting soybean under greenhouse conditions.

\begin{tabular}{|c|c|c|c|c|}
\hline Plant Extracts & $\begin{array}{c}\text { Extraction } \\
\text { medium } \\
\text { (Solvents) } \\
\end{array}$ & $\begin{array}{l}\text { No. galls/ root } \\
\text { system }\end{array}$ & $\begin{array}{c}\text { No. egg } \\
\text { masses/ root } \\
\text { system } \\
\end{array}$ & No. $J_{2} / 250 \mathrm{~g}$ soil \\
\hline \multirow[t]{4}{*}{ Eugenia jambolana } & Distilled water & 180.33 & 27.67 & 680.33 \\
\hline & Ethyl alcohol & 0.00 & 0.00 & 0.00 \\
\hline & Acetone & 110.67 & 7.33 & 300.0 \\
\hline & Mean & 97.00 & 11.67 & 326.78 \\
\hline \multirow[t]{4}{*}{ Punica granatum } & Distilled water & 280.33 & 45.33 & 560.33 \\
\hline & Ethyl alcohol & 20.33 & 0.00 & 0.00 \\
\hline & Acetone & 170.67 & 14.67 & 300.67 \\
\hline & Mean & 157.11 & 20.00 & 287.00 \\
\hline \multirow[t]{4}{*}{ Camellia sinensis } & Distilled water & 90.67 & 25.0 & 320.33 \\
\hline & Ethyl alcohol & 70.33 & 8.33 & 160.00 \\
\hline & Acetone & 170.33 & 31.00 & 400.67 \\
\hline & Mean & 110.44 & 21.44 & 293.67 \\
\hline \multicolumn{2}{|c|}{ Control (nematode only) } & 320.00 & 62.67 & 1600.33 \\
\hline \multicolumn{5}{|c|}{$\mathrm{LSD}_{0.05}$} \\
\hline \multicolumn{2}{|l|}{ Plant extracts $(\mathrm{A})$} & 7.155 & 1.74 & 47.69 \\
\hline \multirow{2}{*}{\multicolumn{2}{|c|}{$\begin{array}{lc}\text { Solvents } \quad(\mathrm{B}) \\
\text { Interactions }(\mathrm{A} \times \mathrm{B})\end{array}$}} & 4.020 & 1.10 & 11.63 \\
\hline & & 8.040 & 2.18 & 23.25 \\
\hline
\end{tabular}

Data are average of 3 replicates.

* Root gall index (RGI) or egg masses index (EI) was determined according to (Taylor and Sasser,1978) where G.I and E.I were determined as follows: $0:=$ no galls, $1=1-2,2=3-10,3=11-30,4=31-100,5=$ more than 100 galls or egg- masses per root system.

The ethyl alcohol leaf extract of $E$.jambolana, completely suppressed gall formation induced by $M$. javanica and egg masses / root system, and the second stage juveniles $\left(\mathrm{J}_{2}\right)$ in soil. The least effective treatment was the aqueous leaf extract of $E$. jambolana in reducing number of root galls (180.33) / root system, gall index (5.0), and the second stage juveniles in the soil ( 680.33 / $250 \mathrm{~g}$ soil). At the same time, ethyl alcohol peel extract of P.granatum showed that the greatest nematicidal effect against M. javanica as root galling was (20.33) galls/ root system, compared with control treatment (320) galls/ root system, in addition to its complete suppressing effect on egg masses per root system, and the second stage juveniles $\left(J_{2}\right)$ in soil. The least effective treatment in reducing root galls (280.33) /, and egg masses (45.33)/ root system, as well as gall, and egg mass indices (5) occurred with the aqueous peel extract of $P$. granatum.

\section{Effect of some natural plant extracts on the growth parameters of soybean plants infected with Meloidogyne javanica}

The growth parameters (root and shoot lengths, fresh and dry weights of roots and shoots) of soybean plants infected with $M$. javanica were measured (Table 4). Ethyl alcohol leaf extract of $E$. jambolana gave the highest shoot fresh weight (17.25 $\mathrm{g}$ ), shoot length $(55.23 \mathrm{~cm})$, root fresh weight $(6.86 \mathrm{~g})$, and root length $(60 \mathrm{~cm})$ compared to $3.52 \mathrm{~g} ; 22.43 \mathrm{~cm} ; 1.93 \mathrm{~g}$ and $22.5 \mathrm{~cm}$ in control treatment, respectively. 
However, plants treated with acetone leaf extract of $C$. sinensis showed the lowest fresh shoot weight $(7.25 \mathrm{~g})$, root fresh weight $(3.25 \mathrm{~g})$, shoot dry weight $(1.69 \mathrm{~g})$, and root dry weight $(0.75 \mathrm{~g})$ compared to $3.52 \mathrm{~g} ; 1.93 \mathrm{~g} ; 0.75 \mathrm{~g}$ and $0.41 \mathrm{~g}$ in control treatment, respectively.

Table 4: Growth parameters of soybean plants infected with Meloidogyne javanica and treated with natural plant extracts.

\begin{tabular}{|c|c|c|c|c|c|c|c|}
\hline Plant Extracts & 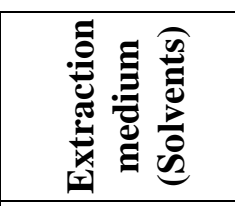 & 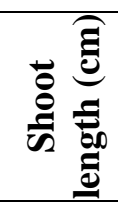 & 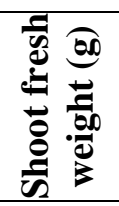 & 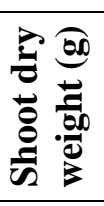 & 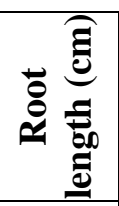 & 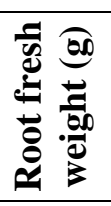 & 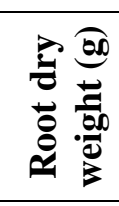 \\
\hline \multirow[t]{4}{*}{ Eugenia jambolana } & Distilled water & 42.33 & 10.36 & 2.25 & 35 & 4.26 & 0.99 \\
\hline & Ethyl alcohol & 55.23 & 17.25 & 3.81 & 60 & 6.86 & 1.68 \\
\hline & Acetone & 35.50 & 7.56 & 1.72 & 31 & 3.89 & 0.89 \\
\hline & Mean & 44.35 & 11.72 & 2.59 & 42 & 5.00 & 1.19 \\
\hline \multirow[t]{4}{*}{ Punica granatum } & Distilled water & 45.52 & 10.38 & 2.93 & 34 & 4.02 & 0.91 \\
\hline & \begin{tabular}{|l|} 
Ethyl alcohol \\
\end{tabular} & 47.56 & 11.16 & 2.55 & 30 & 4.86 & 1.09 \\
\hline & Acetone & 44.83 & 10.25 & 2.28 & 25 & 5.86 & 1.28 \\
\hline & Mean & 45.97 & 10.60 & 2.59 & 29.67 & 4.91 & 1.09 \\
\hline \multirow[t]{4}{*}{ Camellia sinensis } & Distilled water & 45.40 & 12.23 & 2.86 & 37.5 & 5.42 & 1.21 \\
\hline & Ethyl alcohol & 50.36 & 13.25 & 3.05 & 25 & 5.89 & 1.34 \\
\hline & Acetone & 37.50 & 7.25 & 1.69 & 30 & 3.25 & 0.75 \\
\hline & Mean & 44.42 & 10.91 & 2.53 & 30.83 & 4.85 & 1.10 \\
\hline \multirow{2}{*}{\multicolumn{8}{|c|}{ Control (nematode only) }} \\
\hline & & & & & & & \\
\hline Plant extracts (A) & $=$ & 2.99 & 1.35 & 0.32 & 3.31 & 0.44 & 0.19 \\
\hline Solvents & $=$ & 1.72 & 1.02 & 0.23 & 4.59 & 0.47 & 0.13 \\
\hline Interactions $(\mathrm{A} \times \mathrm{B})$ & $=$ & 3.43 & 2.05 & 0.56 & 9.17 & 0.93 & 0.25 \\
\hline
\end{tabular}

Data are averages of 3 replicates.

\section{Chemical composition of leaf extract of $E$. jambolana.}

The components of E. jambolana, leaf extract were identified by the GC-MS chromatogram, the active principles with their retention time (RT), and area sum \%, are presented in Table (5). Thirty- three compounds were identified. The major compounds were 17-octadecynoic acid (10.23\%) and hexadecanoic acid,1(hydroxymethyl)-1.2-ethanediyl ester (9.58\%). Other fatty acids and their esters have also been identified; they were 17-octadecynoic acid, Trans-2-Hexadecenoic acid, Hexadecanoic acid,1-(hydroxymethyl)-1.2-ethanediyl ester) and Phytanic acid.

Three terpenoidal compounds were also recorded; Phytol acetate, Serverogeninactate and Trans-Sesquisabinene hydrate. In addition, several oxogenated hydrocarbons and fatty alcohols were identified; they were 4- Penten2ol,2-Butanol,3-chloro-, $\left(\mathrm{R}^{*}, \mathrm{R}^{*}\right)$-,2-Hexanol, 3-methyl-, 2-Heptadecanol,2-Undecanol, 2-Heptadecanol, 2-hexadecanol,14-octadecenol, 3.7.11.15-tetramethyl-2-hexadecen1-ol. Moreover, there were more antioxidants, Oleic acid, Linolenic acid,2-hydroxy-1(hydroxymethyl) ethyl ester (Z,Z). Two steroidal compounds namely, Ouabagenin and ethyl iso-allocholate were also present. 
Numerous flavonoids compounds were identified as Gardenin flavonoid,5.6.7.3'.4' pentamethoxy flavone, Quercetin 3.5.7.3'.4'-pentamethyl ether, Baicaleintrimethyl ether,Vitexin5.7.2'-trimethoxy flavone,flavanone hydrazine,3-(3.4imethoxyphenyl) -4.6-dimethylcoumarin, 3-(3.4- Dimethoxyphenyl) -7-methyl-4phenyloumarin, 4-hydroxy-2'.34'.6' tetramethoxychalcone, 2-hydroxychalcone, and 2'hydroxy $2.4 ' .5$ tetramethoxychalcone. Furthermore, olomoucine a purine derivative was also recorded in traces.

Table 5: Chemical composition of Eugenia jambolana leaf extract.

\begin{tabular}{|c|c|c|c|}
\hline No. & $\begin{array}{l}\text { Retention } \\
\text { time/min }\end{array}$ & Names of compounds & Area sum\% \\
\hline 1 & 4.53 & 4- Penten-2ol & 2.42 \\
\hline 2 & 4.83 & 2-Butanol,3-chloro-, $\left(\mathrm{R}^{*}, \mathrm{R}^{*}\right)$ - & 3.12 \\
\hline 3 & 7.22 & 2-Hexanol,3-methyl- & 1.17 \\
\hline 4 & 7.77 & 2-Heptadecanol & 4.2 \\
\hline 5 & 8.77 & 2-Undecanol & 3.18 \\
\hline 6 & 9.81 & 2-Heptadecanol & 4.34 \\
\hline 7 & 10.64 & Trans-Sesquisabinene hydrate & 1.6 \\
\hline 8 & 11.31 & Ouabagenin & 5.66 \\
\hline 9 & 11.67 & Gardenin & 1.22 \\
\hline 10 & 12.51 & Flavanone hydrazine & 2.07 \\
\hline 11 & 12.76 & Oleic acid & 1.85 \\
\hline 12 & 12.91 & 17-octadecynoic acid & 10.32 \\
\hline 13 & 13.07 & 3.7.11.15-tetramethyl-2-hexadecen-1-ol & 3.84 \\
\hline 14 & 13.2 & Phytol, acetate & 5.65 \\
\hline 15 & 13.37 & 14 -octadecenol & 0.51 \\
\hline 16 & 13.45 & 5.6.7.3'.4' pentamethoxy flavone & 0.52 \\
\hline 17 & 13.75 & 3-(3.4-imethoxyphenyl)-4.6-dimethylcoumarin & 1.38 \\
\hline 18 & 13.92 & Hexadecanoic acid,1-(hydroxymethyl)-1.2-ethanediyl ester & 9.58 \\
\hline 19 & 14.46 & Ethyl iso-allocholate & 0.96 \\
\hline 20 & 14.94 & Quercetin 3.5.7.3'.4'-pentamethyl ether & 2.36 \\
\hline 21 & 15.11 & Trans-2-Hexadecenoic acid & 1.84 \\
\hline 22 & 15.53 & Baicaleintrimethyl ether & 0.67 \\
\hline 23 & 15.91 & Serverogeninactate & 0.67 \\
\hline 24 & 16.17 & Linolenic acid,2-hydroxy-1-(hydroxymethyl) ethyl ester & 2.21 \\
\hline 25 & 16.78 & $(\mathrm{Z}, \mathrm{Z})$ & 0.74 \\
\hline 26 & 16.83 & 2'-hydroxy 2.4 '.5-tetramethoxychalcone & 0.66 \\
\hline 27 & 20.61 & 2-hexadecanol & 6.34 \\
\hline 28 & 21.72 & Phytanic acid & 1.4 \\
\hline 29 & 21.87 & 4-hydroxy-2'.34'.6'- tetramethoxychalcone & 0.47 \\
\hline 30 & 22.08 & Olomoucine & 0.47 \\
\hline 31 & 22.47 & Vitexin & 1.22 \\
\hline 32 & 22.72 & 2-hydroxychalcone & 0.44 \\
\hline 33 & 22.91 & $\begin{array}{l}\text { 3-(3.4-Dimethoxyphenyl)-7-methyl-4-phenyloumarin } \\
\text { 5.7.2'-trimethoxy flavone }\end{array}$ & 7.86 \\
\hline
\end{tabular}




\section{Biochemical changes in soybean plants infected with $M$. javanica and treated with some natural plant extracts under greenhouse conditions}

All of the tested plant extracts significantly increased the activity of peroxidase enzyme in soybean plants, compared to the control treatment (Table 6). Plants treated with ethyl alcohol and acetone leaf extracts of E. jambolana recorded the highest percentages increases (187.85\% and $163.15 \%$, respectively) in peroxidase activity, while, the lowest percentage increase $(101.59 \%)$ in peroxidase activity was recorded in plants treated with the aqueous leaf extract of $C$. sinensis.

Table 6: Peroxidase (PO), and catalase (CA) enzymes activities in soybean plants infected with Meloidogyne javanica and treated with natural plant extracts under greenhouse conditions.

\begin{tabular}{|c|c|c|c|c|c|}
\hline \multirow{3}{*}{ Plant Extracts } & \multirow{3}{*}{$\begin{array}{l}\text { Extraction } \\
\text { medium } \\
\text { (Solvents) }\end{array}$} & \multicolumn{4}{|c|}{$\begin{array}{c}\text { Enzyme activity } \\
\text { Enzyme unit } \min ^{-1}(\mathrm{mg} \text { protein })^{-1} \text {. }\end{array}$} \\
\hline & & \multicolumn{2}{|c|}{ Peroxidase (PO) } & \multicolumn{2}{|c|}{ Catalase (CA) } \\
\hline & & 冚 & $\therefore$ & 裉 & 。류 \\
\hline \multirow[t]{4}{*}{ E. jambolana } & Distilled water & 1.235 & 146.02 & 11.245 & 49.42 \\
\hline & Ethyl alcohol & 1.445 & 187.85 & 15.428 & 105.00 \\
\hline & Acetone & 1.321 & 163.15 & 13.502 & 79.40 \\
\hline & Mean & 1.334 & 165.67 & 13.392 & 77.94 \\
\hline \multirow{4}{*}{$P$. granatum } & Distilled water & 1.085 & 116.14 & 9.862 & 31.04 \\
\hline & Ethyl alcohol & 1.251 & 149.20 & 11.248 & 49.46 \\
\hline & Acetone & 1.182 & 135.46 & 10.002 & 32.90 \\
\hline & Mean & 1.173 & 133.66 & 10.371 & 37.80 \\
\hline \multirow[t]{4}{*}{ C.sinensis } & Distilled water & 1.012 & 101.59 & 10.002 & 32.90 \\
\hline & Ethyl alcohol & 1.096 & 118.33 & 10.371 & 37.80 \\
\hline & Acetone & 1.069 & 112.95 & 8.368 & 11.19 \\
\hline & Mean & 1.059 & 110.96 & 9.580 & 26.57 \\
\hline \multicolumn{2}{|c|}{ Control (nematode only) } & 0.502 & 0.0 & 7.526 & 0.0 \\
\hline \multicolumn{6}{|c|}{$\mathrm{LSD}_{0.05}$} \\
\hline \multicolumn{2}{|l|}{ Plant extracts (A) } & \multicolumn{2}{|c|}{0.03} & \multicolumn{2}{|c|}{0.23} \\
\hline \multicolumn{2}{|l|}{$\begin{array}{ll}\text { Solvents } & \text { (B) }\end{array}$} & \multirow{2}{*}{\multicolumn{2}{|c|}{$\begin{array}{l}0.04 \\
0.01\end{array}$}} & \multirow{2}{*}{\multicolumn{2}{|c|}{$\begin{array}{l}0.3 \\
0.9\end{array}$}} \\
\hline \multicolumn{2}{|c|}{ Interactions $(\mathrm{A} \times \mathrm{B})$} & & & & \\
\hline
\end{tabular}

Data are average of 3 replicates.

Plants treated with the same previously extracts showed the highest catalase (CA) activities (105.00 and 79.40\%, respectively). While, the lowest percentage increase was recorded in the acetone leaf extract of $C$. sinensis (11.19\%). All of the tested plant extracts significantly increased the activity of chitinase enzyme compared to the control treatment (Table 7). The highest percentage increases were recorded with the ethyl alcohol extract of $P$. granatum, E. jambolana, and C.sinensis $(201.53,157.43$, and $130.12 \%$, respectively). However, its lowest percentage increase in the activity was recorded by aqueous leaf extract of C.sinensis (70.60\%). For $\beta-1,3$ glucanase enzyme activity, the ethyl alcohol leaf extract of E. jambolana treatment recorded the highest increase $(79.19 \%)$, compared to the control treatment. On the other hand, the aqueous peel extract of $P$. granatum treatment recorded the lowest increase in the activity of $\beta-1,3$ glucanase enzyme (7.53\%), compared with other treatments. 
Table 7: Chitinase, and $\beta-1,3$ glucanase enzymes activities in soybean plants infected with Meloidogyne javanica and treated with natural plant extracts under greenhouse conditions.

\begin{tabular}{|c|c|c|c|c|c|}
\hline \multirow{3}{*}{ Plant Extracts } & \multirow{3}{*}{$\begin{array}{l}\text { Extraction } \\
\text { medium } \\
\text { (Solvents) }\end{array}$} & \multicolumn{4}{|c|}{$\begin{array}{c}\text { Enzyme activity } \\
\text { Enzyme unit } \min ^{-1}(\mathrm{mg} \text { protein })^{-1} \text {. }\end{array}$} \\
\hline & & \multicolumn{2}{|c|}{ Chitinase activity } & \multicolumn{2}{|c|}{$\beta-1,3$ glucanase activity } \\
\hline & & Activity & \%Increase & Activity & $\%$ Increase \\
\hline \multirow{4}{*}{ E.jambolana } & Distilled water & 2.596 & 108.51 & 3.968 & 21.42 \\
\hline & Ethyl alcohol & 3.205 & 157.43 & 5.856 & 79.19 \\
\hline & Acetone & 2.695 & 116.47 & 4.528 & 38.56 \\
\hline & Mean & 2.832 & 127.47 & 4.784 & 46.39 \\
\hline \multirow[t]{4}{*}{ P.granatum } & Distilled water & 2.865 & 130.12 & 3.514 & 7.53 \\
\hline & Ethyl alcohol & 3.754 & 201.53 & 4.521 & 38.34 \\
\hline & Acetone & 3.105 & 149.40 & 4.015 & 22.86 \\
\hline & Mean & 3.241 & 160.32 & 4.017 & 22.91 \\
\hline \multirow[t]{4}{*}{ C.sinensis } & Distilled water & 2.124 & 70.60 & 3.869 & 18.39 \\
\hline & Ethyl alcohol & 2.865 & 130.12 & 4.361 & 33.45 \\
\hline & Acetone & 2.632 & 111.41 & 3.856 & 17.99 \\
\hline & Mean & 2.540 & 104.04 & 4.029 & 23.28 \\
\hline \multicolumn{2}{|c|}{ Control (nematode only) } & 1.245 & - & 3.268 & - \\
\hline \multicolumn{6}{|c|}{$\mathrm{LSD}_{0.05}$} \\
\hline \multicolumn{2}{|l|}{$\begin{array}{ll}\text { Plant extracts (A) } \\
\end{array}$} & \multicolumn{2}{|c|}{0.06} & \multicolumn{2}{|r|}{0.12} \\
\hline Solvents & $=$ & \multicolumn{2}{|c|}{0.08} & \multicolumn{2}{|r|}{0.17} \\
\hline Interactions $(\mathrm{A} \times \mathrm{B})$ & $=$ & \multicolumn{2}{|c|}{0.01} & \multicolumn{2}{|c|}{0.01} \\
\hline
\end{tabular}

Data are average of 3 replicates.

\section{Effect of natural plant extracts on the total phenolic compounds (TPC).}

The effect of some natural plant extracts on the phenolic compounds in soybean plants infected with $M$. javanica was determined under greenhouse conditions. Data in Table (8) revealed that all treatments significantly increased the total phenolic contents, compared to the control treatment. The highest percentage increase was recorded with the ethyl alcohol leaf extract of E. jambolana (186.66\%), followed by acetone extract treatment $(153.18 \%)$. The minimal percentage increase was recorded by the aqueous leaf extract of C.sinensis (50.12\%), compared to the other treatments.

\section{DISCUSSION}

Many plants have been known for their medicinal and antimicrobial properties against plant-parasitic nematodes, many years ago (Suberu, 2004). Approximately, 2400 plant species are known to possess biologically active compounds that control various plant pests and pathogens effectively. Our results showed that ethyl alcohol extracts of E. jambolana, $P$. granatum and $C$. sinensis were the most potent in controlling $M$. javanica compared to the aqueous extracts. These results are in agreement with previous results showing that methanol extracts of pomegranate fruit rinds inhibited egg hatching and viability of second-stage juveniles J2 of M. incognita in an in vitro assay (Meyer et al., 2016). 
Table 8: Effect of some natural plant extracts on the total phenolic compounds of soybean plants infected with Meloidogyne javanica under greenhouse conditions.

\begin{tabular}{|c|c|c|c|}
\hline \multirow{2}{*}{ Plant Extracts } & \multirow{2}{*}{$\begin{array}{c}\text { Extraction medium } \\
\text { (solvents) }\end{array}$} & \multicolumn{2}{|c|}{ Total Phenolic contents } \\
\hline & & TPC & \% Increase \\
\hline \multirow[t]{4}{*}{ E.jambolana } & Distilled water & 3.253 & 87.82 \\
\hline & Ethyl alcohol & 4.965 & 186.66 \\
\hline & Acetone & 4.385 & 153.18 \\
\hline & Mean & 4.201 & 142.55 \\
\hline \multirow{4}{*}{ P.granatum } & Distilled water & 3.012 & 73.90 \\
\hline & Ethyl alcohol & 4.215 & 143.36 \\
\hline & Acetone & 3.651 & 110.80 \\
\hline & Mean & 3.626 & 109.35 \\
\hline \multirow{4}{*}{ C.sinensis } & Distilled water & 2.6 & 50.12 \\
\hline & Ethyl alcohol & 3.12 & 80.14 \\
\hline & Acetone & 2.905 & 67.73 \\
\hline & Mean & 2.875 & 65.99 \\
\hline \multicolumn{2}{|c|}{ Control (nematode only) } & 1.732 & - \\
\hline \multicolumn{4}{|c|}{$\mathrm{LSD}_{0.05}$} \\
\hline \multicolumn{2}{|l|}{ Plant extracts (A) } & \multicolumn{2}{|c|}{0.06} \\
\hline \multicolumn{2}{|l|}{ Solvents (B) } & \multicolumn{2}{|c|}{0.08} \\
\hline \multicolumn{2}{|l|}{ Interactions $(\mathrm{A} \times \mathrm{B})$} & \multicolumn{2}{|c|}{0.24} \\
\hline
\end{tabular}

Data are average of 3 replicates.

Similarly, Abdel-Monaim et al. (2017) showed that ethyl alcohol leaf extract of $E$. jambolana was more effective in controlling damping-off and root rot diseases caused by Fusarium solani and Rhizoctonia solani on faba bean plants under in vitro and in vivo. Different solvent kinds have been previously used for the extraction of biologically active compounds from plants. As we found in our results, it was also shown that organic solvents are the most effective in the extraction of antimicrobial compounds when compared to water extracts (Parekh et al.,2005).

In the greenhouse experiment, it was found that the organic solvent extracts of all tested plants were generally more efficient than the aqueous extracts in suppressing the nematode reproduction, compared to the control treatment. As per the in vitro experiment, the ethyl alcohol leaf extract of E. jambolana,was more effective in suppressing gall formation and number of egg masses/plant (root system) developed by $M$. javanica on soybean roots, and number of $\mathrm{J}_{2} \mathrm{~s}$ in soil. This might be due to the bio-active compounds in the plant extracts that might have a nematotoxic effect against $M$. javanica (Knoblock et al., 1989). Actually, there were some bio-active compounds in the GC-MS analysis of leaf extract E. jambolana, which can act singly or in combination against $M$. javanica.These compounds included the flavonoids, which can play multiple defense roles against nematodes involving the inhibition of egg hatching (Wuyts et al., 2006), causing quiescence by slowing down the nematode movement, causing reversible inactivity of the nematodes, repelling the nematode away, or killing them (Birt et al ., 2001; Neuhouser, 2004).

Growth of the soybean plants treated with the tested plant extracts significantly increased, compared to the non-treated control plants. Organic solvent extracts were also the most effective compared to the aqueous extract in this respect. Soybean plants treated with ethyl alcohol leaf extract of E. jambolana exhibited the highest shoot and root weights and lengths in general. This could be explained by the assumption that 
the plant extracts substantially reduced population and damage of $M$. javanica to the infected plant and enhanced plant growth due to their fertilizing ability (Akpheokhai et al., 2012).

Resistance induction in plants is created in activating latent defense mechanisms by means of localized infection by pathogens or as a response to treatment with different biotic agents or abiotic factors (Roberti et al., 2015). Our results revealed that all of the tested plant extracts increased the activities of defense-related enzymes viz. peroxidase, catalase, $\beta-1,3$-glucanases, and chitinases. Ethyl alcohol leaf extract of $E$. jambolana also registered the highest activities of oxidative enzymes, as well as total phenolic contents in soybean plants compared to the other treatments.

The synthesis and accumulation of defense-related enzymes have been frequently found to be associated with plant defense mechanisms against various pathogens (Lebeda et al., 1999).Catalase occurs in peroxisomes and decomposes hydrogen peroxide to water and oxygen. Higher concentrations of $\mathrm{H}_{2} \mathrm{O}_{2}$ regulate programmed cell death, but lower concentrations of $\mathrm{H}_{2} \mathrm{O}_{2}$ participate in many resistance mechanisms, including reinforcement of the plant cell wall, phytoalexin production, and enhancement of resistance to various stresses. The role of peroxidase in plant defense systems is to remove the toxic effect of hydrogen peroxide from tissues and to participate in the synthesis of phenolic compounds and the building of intermolecular bonds to fortify cell walls at the sites of pathogen invasions (Passardi et al., 2004). Both $\beta$-1,3-glucanase and chitinase are well known as PR proteins (Van Loon, 1999). They accumulate in the plants as a response to wounding or infection by pathogens, and there is compelling evidence that $\beta-1,3$-glucanase and chitinase are acting alone and/or particularly in combination to contribute in the plant defenses against fungal infection (Leubner-Metzger and Meins, 1999).

As shown from the results of this study, all of the tested plant extracts increased the levels of total phenolics, compared to the control treatment. Also, the ethyl alcohol leaf extract of $E$. jambolana achieved the highest increase in the levels of total phenolics, compared to other treatments. These results are in agreement with previous reports (Abdel-Monaim et al., 2017). Generally, plants containing high amounts of polyphenols are mostly being resistant to several plant diseases (Malik and Singh, 1980). This increase in total phenols could be attributed to their role in enhancing the defense capabilites of the plants to infectious diseases and development of the pathogens. The toxic phenolic compounds in plant cells were found to act through: 1- the structure of the bond form with cell wall components of plant tissues (Mahadevant and Sridhar, 1986), and 2- enhancing the host resistance by stimulating host defense mechanisms (Subba-Rao et al., 1988).

\section{Acknowledgments}

We are very grateful to Prof. Ahmed A.M. Dawabah, Emeritus Professor of Plant Nematology, Plant Pathology Research Institute, Agricultural Research Center, Egypt, for reviewing of the manuscript. Great thanks to Prof. Abdelrehim Ahmed Ali Moustafa, Professor of Plant Breeding and Agronomy Department, Faculty of Agriculture, Suez Canal University, for statistical analysis of data. 


\section{REFERENCES}

Abbott, W.S. (1925). A method of computing effectiveness of an insecticide. J Economic Entomol.18: 256-267.

Abdel-Monaim ,M.F.; Abo-Elyousr,K.A.M. and Morsy, K.M. (2011). Effectiveness of plant extracts on suppression of damping -off and wilt diseases of lupine (Lupinus termis Forsike). Crop Protect. 30:185-191.

Abdel-Monaim ,M.F. ;Mazen, M.. and Atwa,Marwa. A. M.( 2017). Effectiveness of plant extracts as safe control means against damping-off and root-rot diseases in faba bean plants. Egyptian J Phytopathol.45(1): pp 233-253.

Akpheokhai, I.L. ;Claudius-Cole, A.O. and Fawole, B. (2012). Evaluation of some plant extracts for the management of Meloidogyne incognita on soybean (Glycine max). World J.Agricultural Sci. 8(4): pp.429-435.

Anonymous, (1991).A Software Program for the MSTAT-C Design, Management and Analysis of Agronomic Research Experiments.Michigan State University.

Barker, K.R. ; Carter, C.C. and Sasser, J.N. (1985). An advanced treatise on Meloidogyne.Volume 2: Methodology. Acooperative Publication of the Department of Plant Pathology and the United States Agency for International Development.North Carolina State University.

Birt, D.F.;Hendrich, S. and Wang,W.(2001). Dietary agents in cancer prevention: flavonoids and isoflavonoids. Pharmacology \& therapeutics 90 (2-3): 157177.

Conway, G. (1995). The depletion of natural resources: The impact of food. A 2020 vision for food, agriculture and the environment. International Food Policy Research Institute, Washington, D.C., pp: 125.

Daykin, M. E., and Hussy, R. S. (1985).Staining and histopathological techniques in nematology.Pages 19-35 in: An Advanced Treatise on Meloidogyne.Vol. 1.Biology and Control. Barker K. R.,. Carter C. C, and. Sasser J. N(eds.) North Carolina State University, Raleigh.

El-Nagdi, Wafaa M.A. and Youssef, M.M.A. (2015). Nematicidal effect of some aqueous extracts of botanicals and a commercial bacterial byproduct for biocontrolling root knot nematode, Meloidogyne incognita infecting sugar beet. Scientia Agriculturae 10 (2): 55-58.

FAO. (2018). FAOSTAT. Food and Agriculture organization of the United Nations, Rome, Italy.Available at http:// faostat.fao.org

Fourie, H.; McDonald.A.H. and Loots, G.C. (2001).Plant-parasitic nematodes in field crops in South African Soybean.Nematol. 3: 447-454.

Gomez, K.A. and Gomez, A.A. (1984). Statistical Procedures for Agricultural Research. Wiley-interscience Publication.New York,680p.

Hammerschmidt, R.;Nuckles, E.M. and Kuć.J. (1982). Association of enhanced peroxidase activity with induced systemic resistance of cucumber to Colletotrichum lagenarium. Physiological Plant Pathol .20 (1): 73-82.

Hussey, R.S.and Barker K.R. (1973).Comparison of methods for collecting inocula of Meloidogyne spp., including a new technique. Plant Disease Reporter 57:1025-1028.

Khan, S.A. ;Javed, N.Khan, M.A. Haq,I.U.and Safdar, A. (2011). Use of plant extracts as bare dip root treatment for the management of Meloidogyne incognita. Pakistan J.Phytopathol. 23 (1): 9-13. 
Knoblock, K. ; Weis, K. and Wergent, R. (1989). Mechanism of antimicrobial activity of essential oils.Proceedings of $37^{\text {th }}$ Annual Congress Medicine Plant Research (ACMPR'89), Braunisweig, pp. 5 -9.

Kurabachew, H.and Wydra, K. (2014). Induction of systemic resistance and defenserelated enzymes after elicitacion of resistance by rhizobacteria and silicone application against Ralstonia solanacearum in tomato (Solanum lycopersicum). Crop Protect, Oxford 57: 1-7.

Lebeda, A. ;Kristkova, E. and Dolezal, K. (1999).Peroxidase isozyme polymorphism in Cucurbitapepo cultivars with various morphotypes and different level of field resistance to powdery mildew.Scientia Horticulturae 81:103112.

Leubner-Metzger, G. and Meins, F.J .(1999). Function and regulation of plant $\beta-1,3-$ glucanases. In SK Datta, S Muthukrishnan, eds, Pathogenesis-Related Proteins in Plants. CRC Press, Boca Raton, FL, pp. 49-76.

Liebenberg, A. (2012). Soybean production manual: Your guide to successful soybean production. Potchefstroom: Agricultural Research Council.

Mahadevant, A. and Sridhar K. (1986).Methods of Physiological Plant Pathology. $3^{\text {rd }}$ ed. Sivakami Pub.Madras,India, pp. 1-328.

Malik, C. P. and Singh, M. B. (1980). Estimation of Total Phenols in Plant Enzymology and Histo-Enzymology. Kalyani Publishers, New Delhi, pp. $1-286$

McCord, J.M. and Fridovich, I. (1969). Superoxide dismutase: an enzymic function for erythrocuprein. (HEMOCUPREIN) J Biol Biochem. 244:6049-6055.

Meyer, S.L. ;Chauhan, K.R. and MacDonald, M.H.( 2016). Evaluation of roselle (Hibiscus sabdariffa) leaf and pomegranate (Punica granatum) fruit rind for activity against Meloidogyn incognita. Nematropica 46 (1) :85-96

Neuhouser, M.L.( 2004) .Dietary flavonoids and cancer risk: evidence from human population studies. Nutrition and Cancer 50:1-7.

Ojaghian, M.R. ; Wang, L. Cui, Z.Q. Yang, C. Zhongyun, T.andXie,G.L. (2014 ).Antitifungal and SAR potential of crude extracts derived from neem and ginger against storage carrot rot caused by Sclerotinia sclerotiorum. Industrial Crops and Products, Amsterdam 55 (2): 130-139.

Pan, S.Q. ; Ye, X.S. and Kuć, J.( 1991).Association of $\beta$-1, 3-glucanase activity and isoform pattern with systemic resistance to blue mould in tobacco induced by stem injection with Peronosporatabacina or leaf inoculation with tobacco mosaic virus. Physiological and Molecular Plant Pathol. 39 (1):25-39.

Parekh, ; J. Jadeja, D. and Chanda, S. (2005). Efficacy of aqueous and methanol extracts of some medicinal plants for potential antibacterial activity. Turkish J. Biol. 29: 203-210.

Passardi, F. ;Penel, C. and Dunand, C. (2004).Performing the paradoxical: How plant peroxidases modify the cell wall. Trends in Plant Sci. 9:534-40.

Rahimi, S., Wright, D. J. and Perry, R. N. (1998). Identification and localization of chitinase induced in the roots of potato plants infected with the potato cyst nematode Globodera pallida. Fundamental and Appl Nematol. 21: 705713.

Roberti, R.; Galletti, S. Burzi, P.L. Righini, H. Cetrullo, S.and Perez, C.( 2015).Induction of defense responses in zucchini (Cucurbitapepo) by Anabaena sp. water extract. Biol. Control.82:.61-68. 
Saikia, R. ;Yadav, M. Varghese, S. Singh, B.P. Gogoi, D.K. Kumar, R. and Arora, D.K.(2006). Role of riboflavin in induced resistance against Fusarium wilt and charcoal rot diseases of chickpea. Plant Pathol. J. 22 (4): 339347.

Sikora. ; R.A. Greco.N.andVeloso-Silva, J.F .(2005b) .Nematode parasites of food legumes. In: Luc M. and Sikora R.A., Bridge J. (eds) Plant parasitic nematodes in subtropical and tropical agriculture, 2nd edn. CAB International, Wallingford, pp. 259-318.

Sikora.; R.A. Bridge. J. and Starr,J.L .(2005a). Management practices: an overview of integrated nematode management technologies. In: Luc M., Sikora R.A., In: Luc M., Sikora R.A. and Bridge J. (eds) Plant parasitic nematodes in subtropical and tropical agriculture, 2nd edn. CAB International, Wallingford, pp. 793-825.

Silva, H.S.A.; Romeiro, R.S. Macagnan, D. Halfeld-Vieira, B.A. Pereira, M.C.B.andMounteer, A. (2004).Rhizobacterial induction of systemic resistance in tomato plants: non specific protection and increase enzyme activities. Biol Control. 29 (2) : 288-295.

Stangarlin J.R; Kuhn, O.J, Assi, L. and Schwan-Estrada, K.R.F. (2011). Control of plant diseases using extracts from medicinal plants and fungi. In: MéndezVilas A (ed) Science against microbial pathogens: communicating current research and technological advances. Formatex 3(1) :1033-1042.

Subba-Rao, P.V.; Geigen, J.P. Einhorn, J. Rio, B. Malosse, C. Nicole, M.Savary, S. and Ravise, A. (1988). Host defence mechanisms against groundnut rust. International Arahis Newsletter 4:16-18.

Suberu, H. (2004).Preliminary studies of inhibitions in Asperlagillus fvus with extracts of two lichens and Bentex-T fungicide. African J. Biotechnol. 3: 468-472.

Sultana, N. ;Akhter, M. Khan, R.A.Afzam, N.Tareen,R.B.and Malik .A .(2010).Nematicidal natural products from the aerial parts of Buddleja crispa. Natural Production Research 24: 783-788.

Taylor, A. L. and Sasser, J. N. (1978). Biology, identification and control of root-knot nematodes (Meloidogyne spp.).Corporative publication, Department of Plant Pathology, NC5U and U5AID, Raleigh, North Carolina, p.111.

Van Loon, L.C.( 1999). Occurrence and properties of plant pathogenesis-related proteins. In: Datta SK, Muthukrishnan S, editors. Pathogenesis-Related Proteins in Plants. Boca Raton, FL: CRC Press, pp. 1-19.

Verma, S. and Dubey, R. S. (2003). Lead toxicity induces lipid peroxidation and alters the activities of antioxidant enzymes in growing rice plants. Plant Sci. 164 (4): 645-655.

Weckwerth, W. ; Wenzel, K. and Fiehn, O. (2004). Process for the integrated extraction, identification, and quantification of metabolites, proteins and RNA to reveal their co-regulation in biochemical networks. Proteomics, 4:78-83.

Wirth, S.J. and Wolf, G.A. (1992). Micro-plate colourimetric assay for endo-acting cellulse, xylanase, chitinase, 1,3-beta-glucanase and amylase extracted from forest soil horizons. Soil Biol Biochem. 24:511-519.

Wuyts, N., Swennen, R. and De Waele, D.( 2006).Effects of plant phenylpropanoid pathway products and selected terpenoids and alkaloids on the behaviour of the plant-parasitic nematodes Radopholus similis, Pratylenchus penetrans and Meloidogyne incognita. Nematol. 8(1):89-101. 
Yudelman, M. ;Ratta, A. and Nygaard, D. (1998). Pest Management and Food Production: Looking to the future, Food, Agriculture and the Environment. Discussion Paper 25, International Food Policy Research Institute, USA, pp. 50.

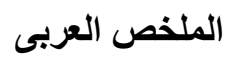

\title{
Meloidogyne تاثير بعض المستخلصات النباتية الطبيعية فى مكافحة نيماتودا تعقد الجذور javanica
}

\author{
سحر حسن عبدالباسط ـ منتصر فوزى عبدالمنعم \\ معهد بحوث امر اض النباتاتـ مركز البحوث الزراعية_الجيزة
}

امكانية استخدام بعض المستخلصات النباتية لها تأثير فى مكافحة النيماتودا المتطفله على النباتات كبديل للمكافحة الكيماوية. فى هذه الدراسة تم استخدام المستخلص المائى و العضوى (كحولـ اسيتون) لثلاثة انو اع من النباتات الطبية وهى اوراق البامبوزيا ـ قثور الرمانـ الثناى الاخضر تحت ظروف المعمل والصوبة فى في مكافحة نيماتودا تعقد الجذور Meloidogyne javanica على فول الصويا صنف جيزة 35. اوضحت النتائج ان المستخلص الكحولى لكلا من أوراق البامبوزيا وقشور الرمان ادى الى تثبيط كلى قى فقس بيض النيماتودا كليا. اما نسبة تثبيط فقس البيض للمستخلص الكحولى لأوراق الثناى الاخضركانت 60٪.فى الوقت ذاته حدث زيادة تدريجية فى نسبة موت اليرقات بزيادة فترة التعرض للمستخلصات من 24 الى 48 ساعة. ايضا اثشارت النتائج أن المستخلصات العضوية لجميع النباتات المختبرة كانت أكثرفاعلية في تقليل تكاثرنيماتودا تعقدالجذور على فول الصويا داخل الصوب، وان المستخلص الكحولى لنبات البامبوزيا ادى الى تثبيط تكوين

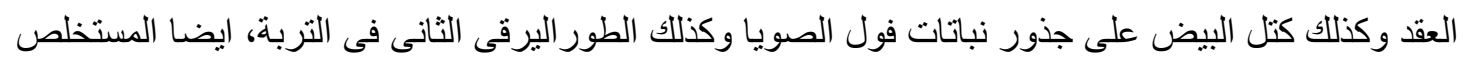
الكحولى لقثور الرمان لله تاثيرفعال فى تثيط تكوين كتل البيض على جذور نبات الصويا وكذلك الطور اليرقى الثانى فى التربة. يعتبر المستخلص المائى لقشور الرمان اقل المعاملات كفاءة فى تقليل اعداد العقد النيماتودية وكتل البيض على الجذوروكذلك اعدادالطور اليرقى الثانى فى التربة.ادت معاملة النباتات بالمستخلص الكحولى لى لـى لأور اق نبات البامبوزيا الى زيادة فى نمو نباتات فول الصويا حيث ادت الى زيادة فى كل من اوزان و اطو ال المجموع الخضرى بالاضافة الى زيادة طول ووزن الجذر مقارنه بالمعاملة الكنترول. اوضح التحليل الكيماوى لمستخلص الكحول لأوراق نبات البامبوزيا باستخدام التحليل الكروموتوجر افى وجود 33 مركب نشط حيويا منها "الفلافونويد ومضادات الأكسدة والهيدروكربونات المؤكسدة والأحماض الدهنية غير المشبعة و إستر الأحماض

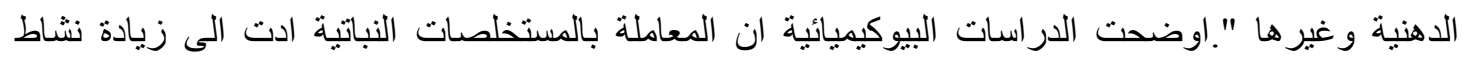
الانزيمات المرتبطة بمقاومة النبات للأمراض مثل انزيمات البيروكسيديز، كاتاليز،شيتينيز، إنزيمات1،3 بيتاجلوكاناز بالاضافة الى محتوى النباتات من الفينولات الكلية فى نباتات فول الصويا المصابة بنيماتودا تعقد 
الجذور فى الصوبة. بشكل عام كانت المستخلصات العضوية للنباتات المختبرة اكثركفاءة من المستخلصات المائية فى زيادة نشاط تلك الانزيمات و الفينو لات الكلية .سجل المستخلص الكحولى لأور اق نبات البامبوزيا اعلى لهي نشاط فى جميع الإنزيمات المختبرة بالاضافه لمحتوى الفينو لات الكلية على نباتات فول الصويا. الكلمات الدالة: Glycine max، تأثثيرمبيدات نيماتودية، انزيمات المقاومة، المركبات الفينولية ، المستخلصات النباتية. 